There will be two speakers for each session, tackling the subjects from different viewpoints. In addition, the Seminar will be divided into four commissions to discuss the broad general field of Afro-European co-operation: rural development in Africa; co-operation in the impact of technological change; Afro-European political relationships and development; communications and Afro-European co-operation.

\title{
Joint Fourah Bay-Berkeley (University of California) Seminar
}

A jorNt seminar of Fourah Bay College and Berkeley, University of California, is to be held at Fourah Bay College, the University College of Sierra Leone, from 20 to 26 June 1966. The subject will be 'Africa in the wider world-the interrelationship of area and comparative studies'. The Joint Seminar Co-ordinators are Mr. Michael Crowder, Director, Institute of African Studies, Fourah Bay College, and Dr. David Brokensha, Chairman, African Studies Committee, University of California, Berkeley. The Secretary is Mr. J. G. Edowu Hyde, Secretary and Research Fellow of the Institute of African Studies, Fourah Bay College.

\section{International Folk Music Council: Eighteenth Conference}

THE eighteenth conference of the International Folk Music Council will be held from 26 July to 4 August 1966, at the University of Ghana, Legon, Accra, by invitation of the Ghana Ministry of Art and Culture. The main themes of the conference will be: the migration of folk-music and its effect on musical style and content, and multi-part techniques in folk-music and dance; musical examples and analyses will be included in all contributions. Further information about the conference may be obtained from the Executive Secretary, Dr. Barbara Krader, International Folk Music Council, Cecil Sharp House, 2 Regent's Park Road, London, N.W.I.

\section{African Studies Association of the United Kingdom: Conference}

THE 1966 Conference will be held in association with the Centre of African Studies, University of Edinburgh, from $2 x$ to 24 September 1966.

After the Presidential Address by Dr. Audrey Richards, Director of the Centre of African Studies, Cambridge, the mornings and afternoons of the two full days of the Conference (Thursday and Friday, 22 and 23 September 1966) will be devoted to plenary, inter-disciplinary sessions organized around two themes: ( 1 ) Africa in the post-war world (involving history, politics, economics, sociology, etc.); and (2) nutrition and ecology. Short papers by two or three speakers for each of the plenary sessions will be circulated in advance of the Conference to members.

\section{A Corpus of Yoruba Bronze Art}

UNDER the auspices of the University of Ife Institute of African Studies the author began in 1963 to assemble a corpus of Yoruba bronze art, including objects held in shrines, in private collections, and in Nigerian and foreign museum institutions. Such a corpus, of a permanent and widely distributed medium of expression, should provide useful data for the study of African art, revealing the growth and development of technique and imagery in the major bronze-casting schools. This corpus is envisaged as the pilot phase of a survey which should cover the practice of bronze art throughout Tropical Africa; it is hoped that it will eventually be contributed to by many hands, particularly from museums and private 